\title{
Optimization of protein production by Micrococcus luteus for exploring pollutant-degrading uncultured bacteria
}

\author{
Xiaomei Su', Yindong Liu', Jinxing Hư ${ }^{1}$, Linxian Ding ${ }^{2}$ and Chaofeng Shen ${ }^{1 *}$
}

\begin{abstract}
The screening of pollutant-degrading bacteria are limited due to most of bacteria in the natural environment cannot be cultivated. For the purpose of resuscitating and stimulating "viable but non-culturable" (VBNC) or uncultured bacteria, Micrococcus luteus proteins are more convenient and cost-effective than purified resuscitationpromoting factor (Rpf) protein. In this study, medium composition and culture conditions were optimized by using statistical experimental design and analysis to enhance protein production by M. luteus. The most important variables influencing protein production were determined using the Plackett-Burman design (PBD) and then central composite design (CCD) was adopted to optimize medium composition and culture conditions to achieve maximum protein yield. Results showed that the maximum protein yield of $25.13 \mathrm{mg} / \mathrm{L}$ (vs. $25.66 \mathrm{mg} / \mathrm{L}$ predicted) was obtained when the mineral solution, Lithium L-lactate, initial $\mathrm{pH}$ and incubation time were set at $1.5 \mathrm{ml} / \mathrm{L}$, $8.75 \mathrm{~g} / \mathrm{L}, 7.5$ and $48 \mathrm{~h}$, respectively. The predicated values calculated with the model were very close to the experimental values. Protein production was obviously increased with optimization fitting well with the observed fluorescence intensity. These results verified the feasibility and accuracy of this optimization strategy. This study provides promising information for exploring highly desirable pollutant-degrading microorganisms.
\end{abstract}

Keywords: Unculture bacteria; Protein production; Micrococcus luteus; Resuscitation-promoting factor; Response surface methodology

\section{Introduction}

To date, just over 7000 well-founded species of bacteria have been described (Epstein 2013), because most of bacteria in the natural environment cannot be cultivated. It is very common for bacteria to survive under extreme conditions by entering into a "viable but non-culturable" (VBNC) state, where the cells are intact and alive and can resuscitate when surrounding conditions are more favorable (Oliver 2005; Oliver 2010; Pawlowski et al. 2011). Although these VBNC or uncultured bacteria can be studied by molecular ecology methods (Vartoukian et al. 2010), to elucidate their related function and genotype, it is necessary to isolate these bacteria and study their microbiology in pure cultures (Kaeberlein et al.

\footnotetext{
* Correspondence: ysxzt@zju.edu.cn

'Department of Environmental Engineering, College of Environmental and Resource Sciences, Zhejiang University, Yuhangtang Road 866\#, Hangzhou 310058, China

Full list of author information is available at the end of the article
}

2002). Meanwhile, the study of VBNC or uncultured bacteria may help explain the nature of microbial uncultivability, and explore the industrial and environmental significance of as-yet-uncultured bacteria.

The most exciting development in resuscitating VBNC bacteria was the discovery of a bacterial cytokine, namely, resuscitation-promoting factor (Rpf), secreted by Micrococcus luteus (Mukamolova et al. 1998). Rpf (activity at picomolar concentrations) could promote the resuscitation and growth of high $\mathrm{G}+\mathrm{C}$ Gram-positive organisms, including Mycobacterium, Rhodococcus, Arthrobacter, Leifsonia, Bacillus, Nocardia, Kitasatospora and Streptomyces (Su et al. 2013). At present, more than 30 genes from various microorganisms coded for "Rpf-like" proteins were grouped into Rpf family (Telkov et al. 2006). Specially, the high-GC Gram-positive bacteria (Actinomycetales), of a family of proteins that act as autocrine growth factors (cytokines) were mainly investigated (Kell and Young 2000). Despite many studies on Rpf 
family proteins and their function in resuscitating VBNC bacteria and stimulating the growth of bacteria (Mukamolova et al. 2002; Panutdaporn et al. 2006; Su et al. 2013), the mechanism of action remains unclear.

Telkov et al. (2006) indicated that Rpf was a peptidoglycanhydrolyzing enzyme, and strongly suggested that this specific activity was responsible for its growth promotion and resuscitation activity. Moreover, Mukamolova et al. (2006) demonstrated that Rpf stimulated bacterial culturability and resuscitation due to its muralytic activity. However, pure Rpf protein, both native (purified from $M$. luteus culture supernatant) and recombinant was prone to lose its activity after storage at $4^{\circ} \mathrm{C}$ for 1 week. Recombinant Rpf protein was also less active than native Rpf protein. Furthermore, in the M. luteus culture supernatant, several other proteins had been found to possess the same muralytic activity as Rpf protein (Mukamolova et al. 2006). The resuscitation and stimulatory activities of proteins from $M$. luteus culture supernatant had been recently verified (Ding 2004; Su et al. 2013; Su et al. 2013). Therefore, for the purpose of resuscitating and stimulating VBNC or uncultured bacteria, proteins from $M$. luteus culture supernatant are more convenient and cost-effective than purified Rpf protein. While some studies have focused on the function of Rpf protein from the perspective of medicine and epidemiology (Dwivedi and Jaykus 2011; Hett and Rubin 2008), little has been done to investigate the capability of proteins from $M$. luteus culture supernatant to aid in culturing difficult-to-culture bacteria, and for exploring potential environmental functions of VBNC or uncultured bacteria.

It is of great significance to use proteins from M. luteus for isolating and culturing highly desirable pollutantdegrading microorganisms, in which case the optimization of medium composition and culture conditions for protein production are very important. To our knowledge, limited information is currently available regarding the optimization of protein production from M. luteus. Conventional methods for multifactor optimization are laborious, time-consuming and cannot predict the true optimum due to interactions between the factors (Giordano et al. 2013; Vasilev et al. 2013). Response surface methodology (RSM) based on factorial design and regression analysis overcomes the limitations of single-factor optimization and is more applicable to multivariable systems (Dash and Gummadi 2007). Although some information may be lost or difficult to interpret in fractional factorial designs, it has been widely applied for product and process improvement (Singh et al. 2013; Song et al. 2012).

The aim of the present study was to optimize the medium composition and culture conditions by RSM. Plackett-Burman design (PBD) was used as the first step to screen for the significant variables. Central composite design (CCD) and response surface analysis were then used to optimize the levels of the screened variables that significantly influenced protein production by M. luteus.

\section{Results and discussion}

Evaluation of significant variables affecting protein production

PBD was applied to determine the relative significance of seven medium components and four culture conditions. The effect of each variable on protein production was estimated by the difference between the average of measurements made at the high level $(+1)$ and the low level $(-1)$ of the particular factor. As shown in Table 1, the protein yield varied from 11.84 to $30.25 \mathrm{mg} / \mathrm{L}$. Using the regression analysis in Table 2, the mineral solution, Lithium L-lactate, initial $\mathrm{pH}$ and incubation time were identified as significant variables affecting protein production.

\section{Optimization of the significant variables for protein production}

The optimal levels for the significant variables and the effect of their interactions on protein production were further investigated by the CCD of RSM. The design matrix and the corresponding experimental results were shown in Table 3. By applying multiple regression analysis to the experimental data, the correlation between significant variables and protein production was established by the following second-order polynomial equation:

$$
\begin{aligned}
\mathrm{Y}= & -204.29+33.41 \mathrm{X}_{3}+4.54 \mathrm{X}_{4} \\
& +49.17 \mathrm{X}_{8}+0.06 \mathrm{X}_{9}-0.06 \mathrm{X}_{3} \mathrm{X}_{4} \\
& -2.20 \mathrm{X}_{3} \mathrm{X}_{8}+0.01 \mathrm{X}_{3} \mathrm{X}_{9}-0.05 \mathrm{X}_{4} \mathrm{X}_{8} \\
& -0.003 \mathrm{X}_{4} \mathrm{X}_{9}+0.04 \mathrm{X}_{8} \mathrm{X}_{9}-4.95 \mathrm{X}_{3}^{2} \\
& -0.22 X_{4}^{2}-3.18 X_{8}^{2}-0.004 X_{9}^{2}
\end{aligned}
$$

where $\mathrm{Y}$ was the predicted protein yield, $\mathrm{X}_{3}, \mathrm{X}_{4}, \mathrm{X}_{8}$ and $\mathrm{X}_{9}$ were the actual values of mineral solution, Lithium L-lactate, initial $\mathrm{pH}$ and incubation time, respectively.

Analysis of variance (ANOVA) and F-test were conducted to evaluate the statistical significance of the fit for Eq. (1) using the Design Expert Software. As shown in Table 4, the Model F-value was 30.11, implying the model was highly significant and there was only lower than $0.01 \%$ chance that the "Model $F$-value" could occur due to noise. The significance of each variable and their interactions were evaluated by the $P$-values, which indicated that $\mathrm{X}_{4}, \mathrm{X}_{8}, \mathrm{X}_{9}, X_{3}^{2}, X_{4}^{2}, X_{8}^{2}$ and $X_{9}^{2}$ were significant model terms. Additionally, the model fit was verified by a high determination coefficient $\left(R^{2}=0.966\right)$, which indicated that $96.6 \%$ of the response variability could be explained. The predicted determination coefficient (Predicted $\mathrm{R}^{2}=0.804$ ) was in reasonable agreement with the 
Table 1 Plackett-Burman design matrix for 11 variables with coded values along with observed results

\begin{tabular}{|c|c|c|c|c|c|c|c|c|c|c|c|c|}
\hline \multirow[t]{2}{*}{ Run } & \multicolumn{11}{|c|}{ Code variable level } & \multirow{2}{*}{$\begin{array}{c}\text { Protein } \\
\text { yield }(\mathrm{mg} / \mathrm{L})\end{array}$} \\
\hline & $\mathrm{X}_{1}$ & $X_{2}$ & $x_{3}$ & $\mathrm{X}_{4}$ & $X_{5}$ & $x_{6}$ & $x_{7}$ & $X_{8}$ & $X_{9}$ & $X_{10}$ & $\mathrm{X}_{11}$ & \\
\hline 1 & +1 & -1 & -1 & -1 & -1 & +1 & -1 & +1 & -1 & -1 & +1 & $13.27 \pm 0.26$ \\
\hline 2 & -1 & +1 & +1 & -1 & +1 & +1 & -1 & -1 & -1 & -1 & +1 & $13.94 \pm 1.57$ \\
\hline 3 & +1 & +1 & -1 & +1 & +1 & -1 & -1 & -1 & -1 & +1 & -1 & $16.42 \pm 0.63$ \\
\hline 4 & +1 & -1 & +1 & +1 & -1 & -1 & -1 & -1 & +1 & -1 & +1 & $16.74 \pm 0.66$ \\
\hline 5 & -1 & +1 & +1 & -1 & -1 & -1 & -1 & +1 & -1 & +1 & -1 & $11.84 \pm 0.08$ \\
\hline 6 & -1 & +1 & -1 & +1 & -1 & +1 & +1 & +1 & +1 & -1 & -1 & $21.60 \pm 0.85$ \\
\hline 7 & +1 & +1 & +1 & +1 & -1 & -1 & +1 & +1 & -1 & +1 & +1 & $20.05 \pm 0.81$ \\
\hline 8 & +1 & +1 & -1 & -1 & +1 & +1 & -1 & +1 & +1 & -1 & -1 & $29.17 \pm 0.47$ \\
\hline 9 & -1 & +1 & +1 & +1 & +1 & -1 & -1 & +1 & +1 & -1 & +1 & $24.56 \pm 0.55$ \\
\hline 10 & +1 & -1 & -1 & +1 & +1 & -1 & +1 & +1 & -1 & -1 & -1 & $18.89 \pm 1.44$ \\
\hline 11 & -1 & +1 & -1 & +1 & +1 & +1 & +1 & -1 & -1 & +1 & +1 & $17.70 \pm 1.12$ \\
\hline 12 & -1 & -1 & +1 & -1 & +1 & -1 & +1 & +1 & +1 & +1 & -1 & $13.19 \pm 1.43$ \\
\hline 13 & +1 & -1 & +1 & -1 & +1 & +1 & +1 & +1 & -1 & -1 & +1 & $13.72 \pm 2.08$ \\
\hline 14 & +1 & +1 & -1 & -1 & -1 & -1 & +1 & -1 & +1 & -1 & +1 & $20.21 \pm 0.67$ \\
\hline 15 & -1 & -1 & -1 & +1 & -1 & +1 & -1 & +1 & +1 & +1 & +1 & $30.25 \pm 0.98$ \\
\hline 16 & -1 & -1 & +1 & +1 & -1 & +1 & +1 & -1 & -1 & -1 & -1 & $17.86 \pm 1.36$ \\
\hline 17 & +1 & -1 & +1 & +1 & +1 & +1 & -1 & -1 & +1 & +1 & -1 & $14.50 \pm 1.11$ \\
\hline 18 & +1 & +1 & +1 & -1 & -1 & +1 & +1 & -1 & +1 & +1 & -1 & $13.94 \pm 0.78$ \\
\hline 19 & -1 & -1 & -1 & -1 & +1 & -1 & +1 & -1 & +1 & +1 & +1 & $16.97 \pm 0.43$ \\
\hline 20 & -1 & -1 & -1 & -1 & -1 & -1 & -1 & -1 & -1 & -1 & -1 & $15.31 \pm 0.32$ \\
\hline
\end{tabular}

adjust determination coefficient (Adjusted $R^{2}=0.934$ ), which also confirmed the significance of the model.

The 3D response surface plots and the corresponding 2D contour plots that graphically represented the regression equations were described. Figures 1 and 2 demonstrated the relationships between response and experimental levels for each variable. Each figure depicted the effect of two variables while keeping the other variables at their zero levels, and the interaction between two variables could be clearly illustrated (Chen et al. 2013). The response surface in each figure was elliptical and the maximum point was determined from the intersection of major and minor axes of the ellipse. As shown in the Figures 1 and 2, maximum protein production could be obtained when the ranges of mineral solution, Lithium L-lactate, initial $\mathrm{pH}$ and incubation time were 1.4-1.8 ml/L, 8-9 g/L, 7.05-7.65 and 40-56 $\mathrm{h}$, respectively. It was important to highlight that the interaction of mineral solution and initial $\mathrm{pH}$ had a significant

Table 2 Variables and test levels for Plackett-Burman experiment ( ${ }^{a}$ indicates model terms are significant)

\begin{tabular}{|c|c|c|c|c|c|}
\hline \multirow[t]{2}{*}{ Code } & \multirow[t]{2}{*}{ Variable } & \multirow{2}{*}{$\begin{array}{c}\text { Low lever } \\
(-1)\end{array}$} & \multirow{2}{*}{$\begin{array}{l}\text { High lever } \\
\quad(+1)\end{array}$} & \multicolumn{2}{|c|}{ Protein yield (mg/L) } \\
\hline & & & & $t$-value & $P$-value \\
\hline$x_{1}$ & $\mathrm{NH}_{4} \mathrm{Cl}(\mathrm{g} / \mathrm{L})$ & 2 & 4 & -0.475 & 0.637 \\
\hline$x_{2}$ & $\mathrm{KH}_{2} \mathrm{PO}_{4}(\mathrm{~g} / \mathrm{L})$ & 1.4 & 2.8 & 1.433 & 0.157 \\
\hline$x_{3}$ & Mineral solution (ml/L) & 1 & 2 & -3.215 & $0.002^{\mathrm{a}}$ \\
\hline$x_{4}$ & Lithium L-lactate (g/L) & 5 & 10 & 2.987 & $0.004^{\mathrm{a}}$ \\
\hline$x_{5}$ & $\mathrm{MgSO}_{4}(\mathrm{~g} / \mathrm{L})$ & 0.03 & 0.06 & -0.151 & 0.88 \\
\hline$x_{6}$ & L-Methionine (g/L) & 0.02 & 0.04 & 0.89 & 0.378 \\
\hline$x_{7}$ & Inosine $(g / L)$ & 1 & 2 & -0.899 & 0.374 \\
\hline$x_{8}$ & Initial pH & 7.5 & 9 & 2.617 & $0.013^{\mathrm{a}}$ \\
\hline$X_{9}$ & Incubation time (h) & 48 & 96 & 3.48 & $0.001^{a}$ \\
\hline$x_{10}$ & Incubation temperature $\left({ }^{\circ} \mathrm{C}\right)$ & 30 & 37 & -1.097 & 0.277 \\
\hline$x_{11}$ & Inculum size (\%) & 2 & 4 & 1.116 & 0.269 \\
\hline
\end{tabular}


Table 3 Central composite design for optimizing significant variables for protein production

\begin{tabular}{|c|c|c|c|c|c|c|}
\hline \multirow[t]{2}{*}{ Run } & \multirow{2}{*}{$\begin{array}{c}\text { Mineral } \\
\text { solution }(\mathrm{ml} / \mathrm{L})\end{array}$} & \multirow{2}{*}{$\begin{array}{c}\text { Lithium } \\
\text { L-lactate }(\mathrm{g} / \mathrm{L})\end{array}$} & \multirow[t]{2}{*}{ Initial pH } & \multirow{2}{*}{$\begin{array}{l}\text { Incubation } \\
\text { time (h) }\end{array}$} & \multicolumn{2}{|c|}{ Protein yield $(\mathrm{mg} / \mathrm{L})$} \\
\hline & & & & & Actual value & Predicted value \\
\hline 1 & 1.5 & 7.5 & 8.25 & 72 & $20.92 \pm 0.45$ & 20.84 \\
\hline 2 & 2 & 5 & 7.5 & 48 & $22.94 \pm 0.23$ & 22.4 \\
\hline 3 & 1.5 & 7.5 & 8.25 & 120 & $1.53 \pm 0.33$ & 1.88 \\
\hline 4 & 1 & 5 & 7.5 & 48 & $21.21 \pm 0.12$ & 20.16 \\
\hline 5 & 2 & 5 & 7.5 & 96 & $13.93 \pm 0.38$ & 12.01 \\
\hline 6 & 2 & 5 & 9 & 48 & $13.11 \pm 0.66$ & 13.32 \\
\hline 7 & 2 & 10 & 9 & 96 & $6.71 \pm 0.49$ & 7.31 \\
\hline 8 & 1.5 & 7.5 & 9.75 & 72 & $7.81 \pm 0.61$ & 7.51 \\
\hline 9 & 1 & 5 & 7.5 & 96 & $9.22 \pm 0.36$ & 9.25 \\
\hline 10 & 1.5 & 2.5 & 8.25 & 72 & $11.71 \pm 0.76$ & 13.05 \\
\hline 11 & 2 & 10 & 9 & 48 & $17.01 \pm 0.43$ & 15.59 \\
\hline 12 & 1 & 5 & 9 & 96 & $4.70 \pm 0.56$ & 6.38 \\
\hline 13 & 1.5 & 7.5 & 8.25 & 72 & $20.31 \pm 0.57$ & 20.84 \\
\hline 14 & 1 & 10 & 7.5 & 96 & $12.08 \pm 0.30$ & 11.41 \\
\hline 15 & 1.5 & 7.5 & 8.25 & 72 & $21.03 \pm 0.49$ & 20.84 \\
\hline 16 & 1.5 & 7.5 & 8.25 & 72 & $21.18 \pm 1.16$ & 20.84 \\
\hline 17 & 1 & 10 & 9 & 96 & $9.00 \pm 0.36$ & 8.16 \\
\hline 18 & 1 & 10 & 9 & 48 & $15.50 \pm 0.89$ & 16.97 \\
\hline 19 & 1.5 & 7.5 & 8.25 & 24 & $19.58 \pm 0.54$ & 21.08 \\
\hline 20 & 1.5 & 7.5 & 8.25 & 72 & $20.97 \pm 0.43$ & 20.84 \\
\hline 21 & 2 & 5 & 9 & 96 & $7.32 \pm 0.53$ & 5.84 \\
\hline 22 & 2 & 10 & 7.5 & 48 & $27.19 \pm 0.35$ & 25.05 \\
\hline 23 & 1 & 10 & 7.5 & 48 & $23.02 \pm 0.34$ & 23.12 \\
\hline 24 & 0.5 & 7.5 & 8.25 & 72 & $15.74 \pm 0.34$ & 15.19 \\
\hline 25 & 2.5 & 7.5 & 8.25 & 72 & $14.17 \pm 0.60$ & 16.57 \\
\hline 26 & 1.5 & 7.5 & 8.25 & 72 & $20.61 \pm 0.83$ & 20.84 \\
\hline 27 & 2 & 10 & 7.5 & 96 & $13.79 \pm 0.74$ & 13.86 \\
\hline 28 & 1 & 5 & 9 & 48 & $15.83 \pm 1.44$ & 14.38 \\
\hline 29 & 1.5 & 7.5 & 6.75 & 72 & $17.69 \pm 0.50$ & 19.84 \\
\hline 30 & 1.5 & 12.5 & 8.25 & 72 & $16.98 \pm 0.31$ & 17.48 \\
\hline
\end{tabular}

negative effect on protein production while a positive interaction was observed between initial $\mathrm{pH}$ and incubation time.

Based on the Eq. (1), the maximum protein production predicted by the Design Expert Software could be achieved when the variables of mineral solution, Lithium L-lactate, initial $\mathrm{pH}$ and incubation time were set at $1.5 \mathrm{ml} / \mathrm{L}$, $8.75 \mathrm{~g} / \mathrm{L}, 7.5$ and $48 \mathrm{~h}$, respectively. The maximum predicted value of protein yield obtained was $25.66 \mathrm{mg} / \mathrm{L}$.

Validation of the models and the optimized conditions In order to confirm the validity of the optimization results, the optimized medium components and culture conditions were evaluated in triplicate which yielded a mean protein value of $25.13 \mathrm{mg} / \mathrm{L}$. The high correlation between the predicted $(25.66 \mathrm{mg} / \mathrm{L})$ and actual $(25.13 \mathrm{mg} / \mathrm{L})$ values confirmed the model validation. Moreover, the maximum protein yield (25.13 $\mathrm{mg} / \mathrm{L})$ obtained after optimization was $24.3 \%$ higher than that obtained without optimization. Apparently, the model was confirmed to be accurate and reliable for predicting protein production by $M$. luteus.

In proteins, the tryptophan is the constituent amino acids with the highest fluorescence emission. And the fluorescence spectrum of a protein is determined by the dominant fluorescent tryptophan (Keeratiurai et al. 2012; Mendonça et al. 2013). Hence, the changes in the tryptophan spectrum were used to indicate the changes of protein concentration. Emission fluorescence spectra of 
Table 4 ANOVA for response surface quadratic model for protein production

\begin{tabular}{|c|c|c|c|c|c|}
\hline \multirow[t]{2}{*}{ Factors } & \multicolumn{5}{|c|}{ Statistics } \\
\hline & Sum of squares & df & Mean square & $F$-value & $P$-value \\
\hline Model & 1075.47 & 14 & 76.82 & 30.11 & $<0.0001$ \\
\hline$x_{3}$ & 2.88 & 1 & 2.88 & 1.13 & 0.3051 \\
\hline$X_{4}$ & 29.42 & 1 & 29.42 & 11.53 & 0.0040 \\
\hline$x_{8}$ & 227.79 & 1 & 227.79 & 89.29 & $<0.0001$ \\
\hline$x_{9}$ & 552.46 & 1 & 552.46 & 216.56 & $<0.0001$ \\
\hline$x_{3} x_{4}$ & 0.10 & 1 & 0.10 & 0.038 & 0.8475 \\
\hline$x_{3} x_{8}$ & 10.90 & 1 & 10.90 & 4.27 & 0.0565 \\
\hline$x_{3} X_{9}$ & 0.27 & 1 & 0.27 & 0.10 & 0.7507 \\
\hline$X_{4} X_{8}$ & 0.15 & 1 & 0.15 & 0.06 & 0.8147 \\
\hline$X_{4} X_{9}$ & 0.64 & 1 & 0.645 & 0.25 & 0.6225 \\
\hline$X_{8} X_{9}$ & 8.43 & 1 & 8.43 & 3.30 & 0.0892 \\
\hline$X_{3}^{2}$ & 42.09 & 1 & 42.09 & 16.50 & 0.0010 \\
\hline$X_{4}^{2}$ & 53.19 & 1 & 53.19 & 20.85 & 0.0004 \\
\hline$X_{8}^{2}$ & 87.85 & 1 & 87.85 & 34.44 & $<0.0001$ \\
\hline$X_{9}^{2}$ & 150.01 & 1 & 150.01 & 58.80 & $<0.0001$ \\
\hline Residual & 38.27 & 15 & 2.55 & & \\
\hline Pure error & 0.51 & 5 & 0.10 & & \\
\hline Cor total & 1113.73 & 29 & & & \\
\hline
\end{tabular}

Coefficient of determination $\left(\mathrm{R}^{2}=0.966\right), \mathrm{R}^{2}$ (predict $)=0.804, \mathrm{R}^{2}$ (adjust $)=0.934$.

protein concentration in $M$. luteus culture supernatant with and without optimization were shown in Figure 3. It was apparent that the $M$. luteus culture supernatant had maximum fluorescence intensity at $350 \mathrm{~nm}$ (excitation at $280 \mathrm{~nm})$ which was typical for tryptophan $\left(\lambda_{\mathrm{ex}}\right.$ $280 \mathrm{~nm}, \lambda_{\mathrm{em}} 350 \mathrm{~nm}$ ). It is interesting to point out that a maximum of 2 -fold increase in fluorescence was achieved with optimization. In addition, two peaks (peak A and peak B) with relatively high fluorescence intensity could be obviously observed in the threedimensional fluorescence contour map (Figure 4). As shown in Figure 4, the first main peak was identified at excitation/emission wavelengths (Ex/Em) of 350-400/ 415-475 $\mathrm{nm}$ (peak B), while the second main peak was identified at Ex/Em of 280-290/325-375 nm (peak A). Compared with Figure 4A, the fluorescence intensity of peak $A$ in Figure 4B was significantly increased, while the fluorescence intensity of peak B was decreased. Generally, fluorescence peaks with $\mathrm{Em}<380 \mathrm{~nm}$ represent protein-like substances, and fluorescence peaks with $\mathrm{Em}>380 \mathrm{~nm}$ represent humic-like substances (Murphy et al. 2011; Li et al. 2013). In this study, peak B had been described as protein-like peaks, in which the fluorescence is associated with the aromatic amino acid tryptophan. Thus, fluorescence intensity of proteins increased obviously after optimization. In addition, it was worth to note that fluorescence intensity of humic-like substances was much stronger than that of proteins, which demonstrated that protein concentration was relatively low in M. luteus culture supernatant. Recently, the resuscitation and stimulatory activities of proteins from $M$. luteus culture supernatant had been widely accepted (Ding 2004; Su et al. 2013; Su et al. 2013). It can thus provide some clues that $\mathrm{Rpf}$ at picomolar concentrations could greatly promote the resuscitation and growth of bacteria (Mukamolova et al. 1998; Mukamolova et al. 2006). In addition, the effect of proteins from $M$. luteus on the performance of biphenyl biodegradation and bacterial community in polychlorinated biphenyl (PCB)contaminated sediments near e-waste recycling sites from Taizhou area (Shen et al. 2007) was investigated. After medium composition and culture conditions optimization, proteins in culture supernatants of $M$. luteus present enhanced activity in resuscitating and stimulating biphenyldegrading bacteria (data not shown).

At present, increasing concern has surrounded the limitations of current bioremediation which include the poor capabilities of microbial communities in the field (Megharaj et al. 2011). M. luteus protein, as an efficient approach to resuscitate and stimulate the VBNC or uncultured bacteria, was a promising method for exploring highly desirable pollutant-degrading microorganisms (Su et al. 2013). Enhancing production of M. luteus protein provides a new insight into bacterial degradation of pollutants and is helpful for efficacy testing of bioremediation.

\section{Conclusions}

Plackett-Burman design and central composite design were employed to rapidly identify significant variables as well as to optimize medium composition and culture conditions for protein production by Micrococcus luteus. The results indicated that maximum protein production could be achieved when the significant variables of mineral solution, Lithium L-lactate, initial $\mathrm{pH}$ and incubation time were set at $1.5 \mathrm{ml} / \mathrm{L}, 8.75 \mathrm{~g} / \mathrm{L}, 7.5$ and $48 \mathrm{~h}$, respectively. The predicated values calculated with the model coincided with the experimental values. Protein concentration in the $M$. luteus culture supernatant was obviously increased with optimization, which fitted well with the observed fluorescence intensity. The results confirmed the validity and practicability of this statistical optimization strategy.

\section{Methods}

\section{Microorganisms and cultivation}

Micrococcus luteus IAM 14879 (=JCM $21373=$ NCIMB 13267) (Ding 2004; Mukamolova et al. 1998) was used in the present study. Cultures were grown in lactate minimal medium (LMM) containing (per liter): $4.0 \mathrm{~g} \mathrm{NH}_{4} \mathrm{Cl}$, $1.4 \mathrm{~g} \mathrm{KH}_{2} \mathrm{PO}_{4}, 0.005 \mathrm{~g}$ Biotin, $0.02 \mathrm{~g}$ L-Methionine, $0.04 \mathrm{~g}$ Thiamine $\mathrm{B} 1,1.0 \mathrm{~g}$ Inosine, $0.03 \mathrm{~g} \mathrm{MgSO}_{4}, 10.0 \mathrm{~g}$ Lithium 

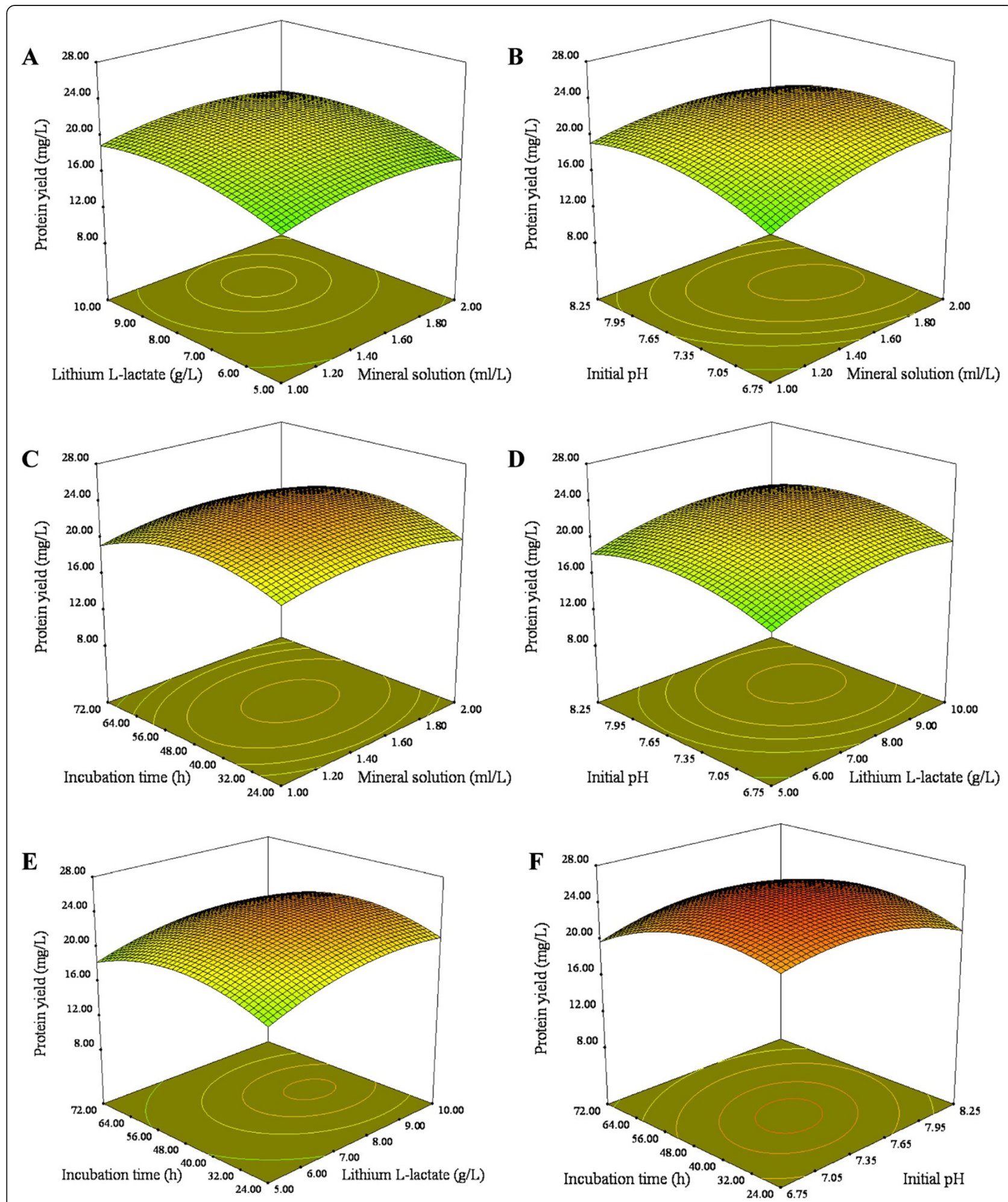

Figure 1 Response surface plot showing interactive effect of selected variables on protein yield by M. luteus. (A) Mineral solution and Lithium L-lactate, (B) Mineral solution and initial pH, (C) Mineral solution and incubation time, (D) Lithium L-lactate and initial pH, (E) Lithium L-lactate and incubation time, (F) Initial pH and incubation time. 

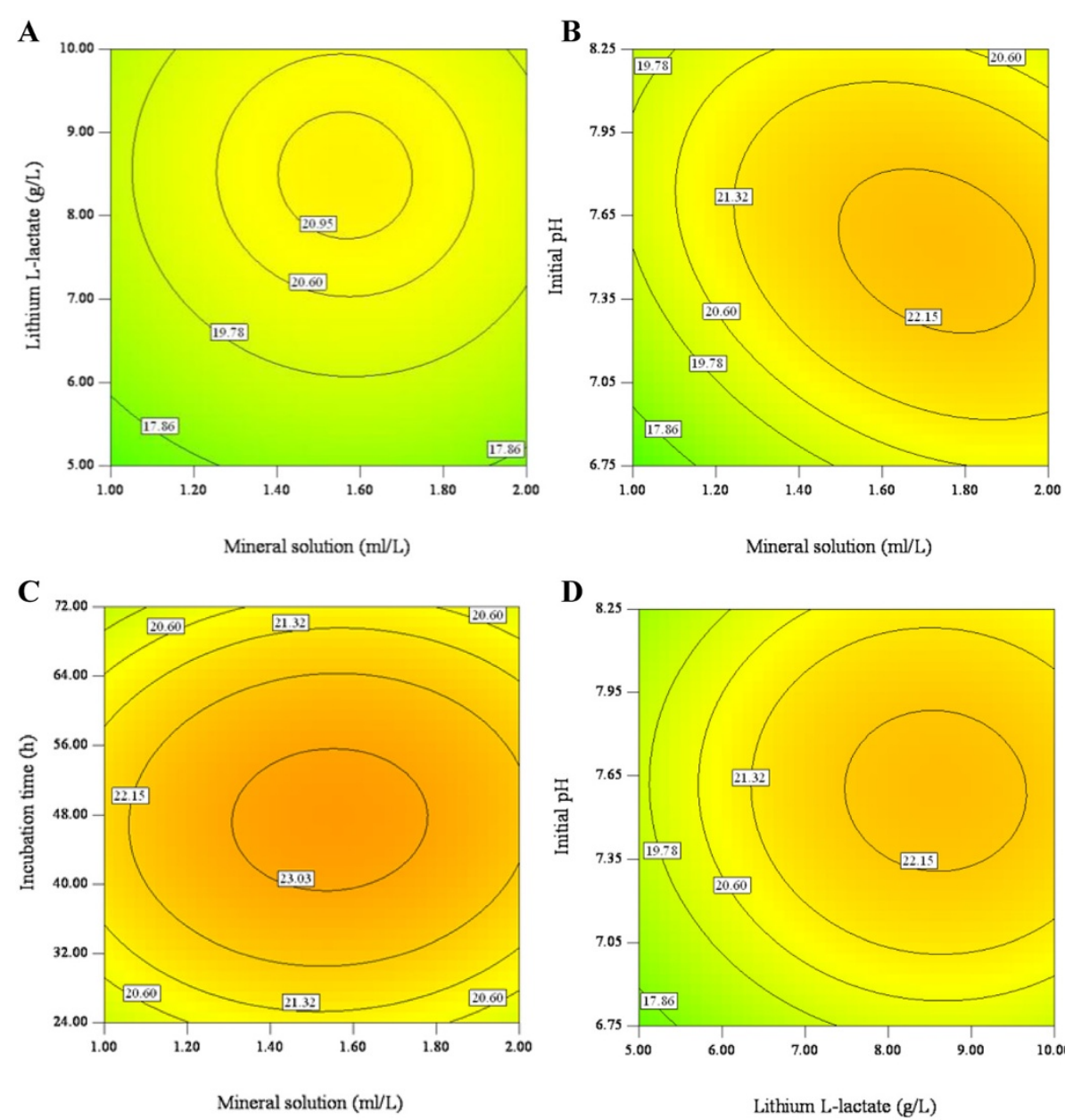

D
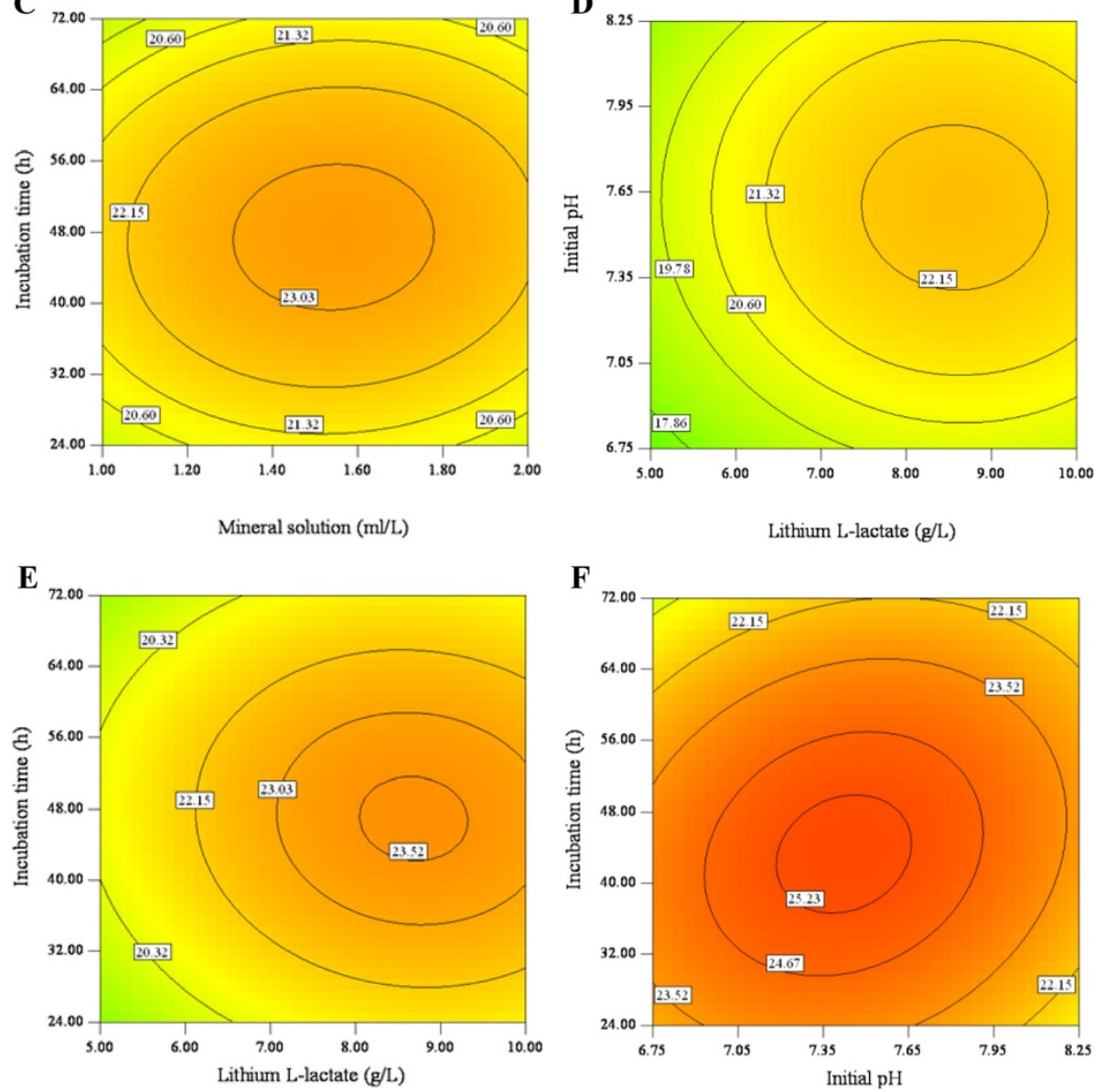

Figure 2 Contour plot showing interactive effect of selected variables on protein yield by M. luteus. (A) Mineral solution and Lithium L-lactate, (B) Mineral solution and initial pH, (C) Mineral solution and incubation time, (D) Lithium L-lactate and initial pH, (E) Lithium L-lactate and incubation time, (F) Initial pH and incubation time.

L-lactate, and $1.0 \mathrm{~mL}$ of trace element solution, adjusted to $\mathrm{pH}$ 7.5. The trace element solution contained (per liter): $0.375 \mathrm{~g} \mathrm{CuSO}_{4} \cdot 5 \mathrm{H}_{2} \mathrm{O}, 0.785 \mathrm{~g} \mathrm{MnCl}_{2} \cdot 4 \mathrm{H}_{2} \mathrm{O}, 0.183 \mathrm{~g}$ $\mathrm{FeSO}_{4} \cdot 7 \mathrm{H}_{2} \mathrm{O}, 0.029 \mathrm{~g} \mathrm{Na} \mathrm{MoO}_{4} \cdot 2 \mathrm{H}_{2} \mathrm{O}$, and $0.089 \mathrm{~g}$ $\mathrm{ZnSO}_{4} \cdot 7 \mathrm{H}_{2} \mathrm{O}$. Seed cultures were prepared by transferring a pure culture into a $250 \mathrm{~mL}$ flask containing $80 \mathrm{~mL}$ of LMM medium and inoculating at $30^{\circ} \mathrm{C}$ on a rotary shaker at $160 \mathrm{rpm}$ for $36 \mathrm{~h}$. A portion of the seed culture was used to inoculate LMM medium ( $4 \%, \mathrm{v} / \mathrm{v})$ which was cultured as previously described until the cells reached 


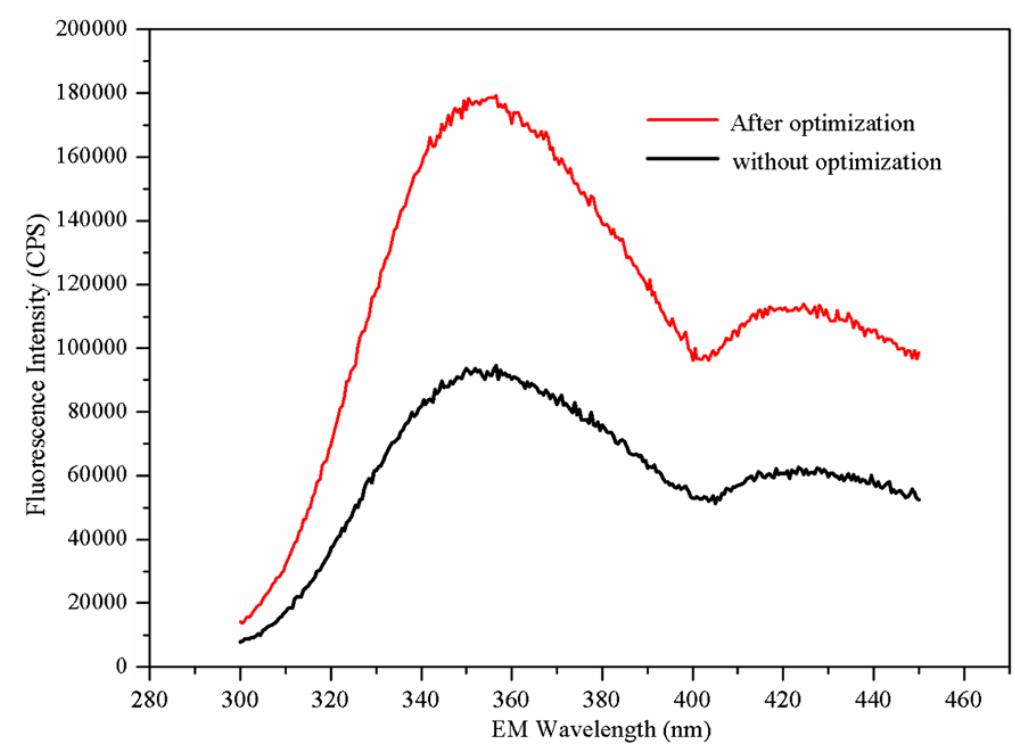

Figure 3 Emission fluorescence spectra of protein yield in $M$. luteus culture supernatant with and without optimization.

stationary phase. For the optimization experiments, medium composition and culture conditions were varied according to experimental design.

\section{Determination of protein yield}

The resultant culture was centrifuged (8000 rpm, $15 \mathrm{~min}$ ) to separate the cells, the centrifugal supernatant filtered through a $0.22 \mu \mathrm{m}$ filter to remove floating cells and the supernatant assayed for protein yield. Protein content was measured using a modified Bradford Protein Assay Kit (Sangon Biotech, Shanghai, China) and plate read at $595 \mathrm{~nm}$ in a microplate reader (Thermo Scientific, Rockford, USA) (Ma et al. 2013). A standard curve was created using bovine serum albumin (BSA) protein, and protein concentration of samples was determined by comparison to the standard curve.

\section{Experimental design and statistical analysis Plackett-Burman design}

Plackett-Burman design is an effective technique for screening and evaluating significant factors that influence a response. The technique is based on the following first-order polynomial model:

$$
Y=\beta_{0}+\sum_{i=1}^{k} \beta_{i} X_{\mathrm{i}}
$$

where $Y$ represents the response (protein yield), $\beta_{0}$ is the model intercept, $\beta_{i}$ is the linear coefficient, $X_{\mathrm{i}}$ is the level of the independent variable, and $k$ represents the number of variables (Feng et al. 2010; Liu et al. 2010).

Seven medium components $\left(\mathrm{NH}_{4} \mathrm{Cl}, \mathrm{KH}_{2} \mathrm{PO}_{4}\right.$, L-Methionine, $\mathrm{MgSO}_{4}$, Inosine, mineral solution and Lithium L-lactate) and four culture conditions (initial $\mathrm{pH}$, incubation time, incubation temperature and inoculum size) were investigated to determine the significant variables affecting protein production. Based on $\mathrm{PBD}$, each variable was prepared at two levels -1 for low level and +1 for high level. Table 2 showed the levels of each variable and the 13 variables were investigated in 20 experimental runs (Table 1). All the runs were performed in triplicate and the average value was used as the response. The variables significant at a $95 \%$ level $(P<0.05)$ were deemed to have a significant effect on protein production, and were evaluated in further optimization experiments.

\section{Central composite design}

Based on the results of PBD, the significant variables of mineral solution $\left(\mathrm{X}_{3}\right)$, Lithium L-lactate $\left(\mathrm{X}_{4}\right)$, initial $\mathrm{pH}$ $\left(\mathrm{X}_{8}\right)$ and incubation time $\left(\mathrm{X}_{9}\right)$ were further optimized using Central composite design. A $2^{4} \mathrm{CCD}$ with six replicates at the central point leading to 30 experiments was employed to optimize the conditions for improving protein yield. For statistical calculations, the relationship between the coded values and actual values are described by the following equation:

$$
X_{i}=\left(A_{i}-A_{0}\right) / \Delta A_{i}
$$

where $X_{i}$ and $A_{i}$ are the coded value and actual value of the independent variable, respectively, $A_{0}$ is the actual value of the $A_{i}$ at the central point, and $\Delta A_{i}$ is the step change (Cao et al. 2010). According to the dependent variable of protein yield, each of the four variables was evaluated at five coded levels $(-2,-1,0,+1$ and +2$)$ and the final values were shown in Table 3. 

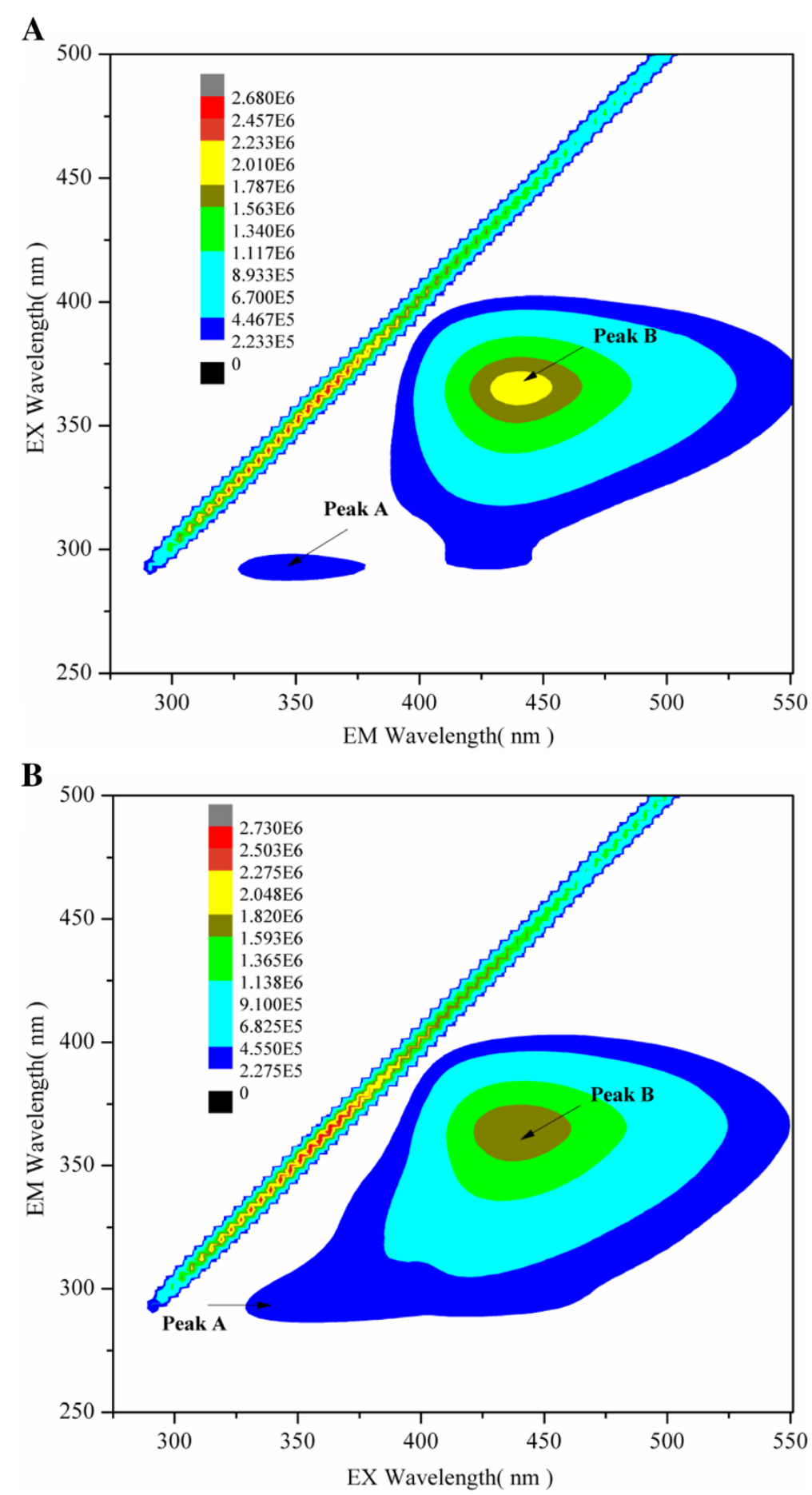

Figure 4 Fluorescence spectra of culture supernatant from $M$. luteus with and without optimization. (A) Without optimization, (B) With optimization, Peak A: protein-like substances, Peak B: humic-like substances.

For predicting the optimal point, a second-order quadratic equation describing the relationship between independent variable and response was developed. Designbased experimental data is used to fit a second-order polynomial equation:

$$
\Upsilon=\beta_{0}+\sum_{i=1}^{4} \beta_{i} X_{i}+\sum_{i=1}^{4} \beta_{i i} X_{i}^{2}+\sum_{i, j=1}^{4} \beta_{i j} X_{i} X_{j}
$$

where $\mathrm{Y}$ is the predicted response, $\beta_{0}$ is the interception coefficient, $\beta_{i}$ is the linear coefficient, $\beta_{i i}$ is the quadratic 
coefficient, and $\beta_{i j}$ is the interactive coefficient (Körbahti and Rauf 2009; Mizumoto and Shoda 2007).

\section{Statistical analysis}

Design-Expert software (Version 8.0.5.0, Stat-Ease Inc., Minneapolis, USA) was used for regression and graphical analyses of the data. All experiments were performed in triplicate and the average of means was calculated. SPSS software (version 18.0) was used for data analysis and statistical analysis of the standard deviation (SD) to determine statistical significance.

\section{Validation of the models and the optimized conditions}

The validation experiments were conducted under the optimized medium composition and culture conditions. By comparing the actual and predicted values, the validation of the models was investigated. In addition, the change of protein concentration in M. luteus culture supernatant with and without optimization was measured. And then M. luteus culture supernatant was analyzed by monitoring changed induced by optimization in synchronous fluorescence and three-dimensional fluorescence spectra. All fluorescence spectra were recorded on a Fluoromax-4 spectrometer (Horiba Co., Ltd. Kyoto, Japan) equipped with $1.0 \mathrm{~cm}$ quartz cells and a thermostat bath. M. luteus culture supernatant fluorescence emission spectra $\left(\lambda_{\text {ex }} 280 \mathrm{~nm}, \lambda_{\text {em }} 300-\right.$ $450 \mathrm{~nm}$ ) were measured with excitation and emission slits both at $5 \mathrm{~nm}$ (Keeratiurai et al. 2012). The threedimensional fluorescence spectrum was performed according to the modified method by Jiang et al. (Jiang et al. 2013): the emission and excitation wavelengths were at 275-550 nm and 250-500 nm, respectively. The widths of the emission slit and excitation slit were set to 2.0 and $4.0 \mathrm{~nm}$, respectively.

\section{Competing interests}

The authors declare that they have no competing interests.

\section{Authors' contribution}

CS and XS proposed the study. XS and YL collected and reviewed the contents of the manuscript under the guidance of LD and CS. JH carried out the experiments. All the authors have read the article and approved the final manuscript.

\section{Acknowledgements}

We gratefully acknowledge the financial support provided by the Fundamental Research Funds for the Central Universities,the National Natural Science Foundation of China (41271334), the National High Technology Research and Development Program of China (2012AA06A203), and Zhejiang Provincial Natural Science Foundation of China (LR12D01001).

\section{Author details}

'Department of Environmental Engineering, College of Environmental and Resource Sciences, Zhejiang University, Yuhangtang Road 866\#, Hangzhou 310058, China. ${ }^{2}$ College of Geography and Environmental Science, Zhejiang Normal University, Jinhua 321004, China.

Received: 21 December 2013 Accepted: 13 February 2014 Published: 28 February 2014

\section{References}

Cao GL, Ren NQ, Wang AJ, Guo WQ, Yao J, Feng YJ, Zhao QL (2010) Statistical optimization of culture condition for enhanced hydrogen production by Thermoanaerobacterium thermosaccharolyticum W16. Bioresour Technol 101:2053-2058

Chen WC, Yu WJ, Chang CC, Chang JS, Huang SH, Chang CH, Chen SY, Chien CC, Yao CL, Chen WM (2013) Enhancing production of prodigiosin from Serratia marcescens C3 by statistical experimental design and porous carrier addition strategy. Biochem Eng J 78:93-100

Dash SS, Gummadi SN (2007) Enhanced biodegradation of caffeine by Pseudomonas sp. using response surface methodology. Biochem Eng J 36:288-293

Ding LX (2004) Studies on the Isolation of Viable but Non-Culturable Bacteria and the Phylogenetic Analysis of the Genus Aquaspirillum. The University of Tokyo Ph. D. Dissertation, Tokyo

Dwivedi HP, Jaykus LA (2011) Detection of pathogens in foods: the current state-of-the-art and future directions. Crit Rev Microbiol 37:40-63

Epstein SS (2013) The phenomenon of microbial uncultivability. Curr Opin Microbiol 16:636-642

Feng YL, Li WQ, Wu XQ, Cheng JW, Ma SY (2010) Statistical optimization of media for mycelial growth and exo-polysaccharide production by Lentinus edodes and a kinetic model study of two growth morphologies. Biochem Eng J 49:104-112

Giordano PC, Beccaria AJ, Goicoechea HC, Olivieri AC (2013) Optimization of the hydrolysis of lignocellulosic residues by using radial basis functions modelling and particle swarm optimization. Biochem Eng J 80:1-9

Hett EC, Rubin EJ (2008) Bacterial growth and cell division: a mycobacterial perspective. Microbiol Mol Biol Rev 72:126-156

Jiang CY, Yuan Y, Sun ZJ, Ye SM, Chen H, Pan QM (2013) Effect of hydrostatic pressure and $\mathrm{pH}$ value on the three-dimensional fluorescence spectrum of tyrosine solution with various concentrations of copper ion. J Lumin 135:42-46

Körbahti BK, Rauf MA (2009) Determination of optimum operating conditions of carmine decoloration by $\mathrm{UV} / \mathrm{H}_{2} \mathrm{O}_{2}$ using response surface methodology. J Hazard Mater 161:281-286

Kaeberlein T, Lewis K, Epstein SS (2002) Isolating "uncultivable" microorganisms in pure culture in a simulated natural environment. Science 296:1127-1129

Keeratiurai M, Miriani M, lametti S, Bonomi F, Corredig M (2012) Structural changes of soy proteins at the oil-water interface studied by fluorescence spectroscopy. Colloids Surf B 93:41-48

Kell DB, Young M (2000) Bacterial dormancy and culturability: the role of autocrine growth factors: commentary. Curr Opin Microbiol 3:238-243

Li WT, Xu ZX, Li AM, Wu W, Zhou Q, Wang JN (2013) HPLC/HPSEC-FLD with multi-excitation/emission scan for EEM interpretation and dissolved organic matter analysis. Water Res 47:1246-1256

Liu S, Fang YW, Lv MS, Wang SJ, Chen L (2010) Optimization of the production of organic solvent-stable protease by Bacillus sphaericus DS11 with response surface methodology. Bioresour Technol 101:7924-7929

Ma MG, Wang X, Zhang XP, Zhao XX (2013) Alcohol dehydrogenases from Scheffersomyces stipitis involved in the detoxification of aldehyde inhibitors derived from lignocellulosic biomass conversion. Appl Microbiol Biotechnol 97:8411-8425

Megharaj M, Ramakrishnan B, Venkateswarlu K, Sethunathan N, Naidu R (2011) Bioremediation approaches for organic pollutants: a critical perspective. Environ Int 37:1362-1375

Mendonça A, Rocha AC, Duarte AC, Santos EBH (2013) The inner filter effects and their correction in fluorescence spectra of salt marsh humic matter. Anal Chim Acta 788:99-107

Mizumoto S, Shoda M (2007) Medium optimization of antifungal lipopeptide, iturin A, production by Bacillus subtilis in solid-state fermentation by response surface methodology. Appl Microbiol Biotechnol 76:101-108

Mukamolova GV, Kaprelyants AS, Young DI, Young M, Kell DB (1998) A bacterial cytokine. Proc Natl Acad Sci U S A 95:8916-8921

Mukamolova GV, Murzin AG, Salina EG, Demina GR, Kell DB, Kaprelyants AS, Young M (2006) Muralytic activity of Micrococcus luteus Rpf and its relationship to physiological activity in promoting bacterial growth and resuscitation. Mol Microbiol 59:84-98

Mukamolova GV, Turapov OA, Young DI, Kaprelyants AS, Kell DB, Young M (2002) A family of autocrine growth factors in Mycobacterium tuberculosis. Mol Microbiol 46:623-635

Murphy KR, Hambly A, Singh S, Henderson RK, Baker A, Stuetz R, Khan SJ (2011) Organic matter fluorescence in municipal water recycling schemes: toward a unified PARAFAC model. Environ Sci Technol 45:2909-2916 
Oliver JD (2005) The viable but nonculturable state in bacteria. J Microbiol 43:93-100

Oliver JD (2010) Recent findings on the viable but nonculturable state in pathogenic bacteria. FEMS Microbiol Rev 34:415-425

Panutdaporn N, Kawamoto K, Asakura H, Makino SI (2006) Resuscitation of the viable but non-culturable state of Salmonella enterica serovar Oranienburg by recombinant resuscitation-promoting factor derived from Salmonella Typhimurium strain LT2. Int J Food Microbiol 106:241-247

Pawlowski DR, Metzger DJ, Raslawsky A, Howlett A, Siebert G, Karalus RJ, Garrett S, Whitehouse CA (2011) Entry of Yersinia pestis into the viable but nonculturable state in a low-temperature tap water microcosm. Plos One $6: 1-9$

Shen CF, Huang SB, Wang ZJ, Qiao M, Tang XJ, Yu CN, Shi DZ, Zhu YF, Shi JY, Chen XC (2007) Identification of Ah receptor agonists in soil of e-waste recycling sites from Taizhou area in China. Environ Sci Technol 42:49-55

Singh P, Shera SS, Banik J, Banik RM (2013) Optimization of cultural conditions using response surface methodology versus artificial neural network and nodeling of L-Glutaminase production by Bacillus cereus MTCC 1305. Bioresour Technol 137:261-269

Song L, Qin JG, Su SQ, Xu JH, Clarke S, Shan YC (2012) Micronutrient requirements for growth and hydrocarbon production in the oil producing green alga Botryococcus braunii (Chlorophyta). PloS One 7:e41459

Su XM, Chen X, Hu JX, Shen CF, Ding LX (2013a) Exploring the potential environmental functions of viable but non-culturable bacteria. World J Microbiol Biotechnol 29:2213-2218

Su XM, Ding LX, Hu JX, Shen CF, Chen YX (2013b) A novel approach to stimulate the biphenyl-degrading potential of bacterial community from PCBscontaminated soil of e-waste recycling sites. Bioresour Technol 146:27-34

Telkov MV, Demina GR, Voloshin SA, Salina EG, Dudik TV, Stekhanova TN, Mukamolova GV, Kazaryan KA, Goncharenko V, Young M, Kaprelyants AS (2006) Proteins of the Rpf (resuscitation promoting factor) family are peptidoglycan hydrolases. Biochem Mosc 71:414-422

Vartoukian SR, Palmer RM, Wade WG (2010) Strategies for culture of unculturable'bacteria. FEMS Microbiol Lett 309:1-7

Vasilev N, Grömping U, Lipperts A, Raven N, Fischer R, Schillberg S (2013) Optimization of BY-2 cell suspension culture medium for the production of a human antibody using a combination of fractional factorial designs and the response surface method. Plant Biotechnol J 11:867-874

doi:10.1186/2193-1801-3-117

Cite this article as: Su et al:: Optimization of protein production by

Micrococcus luteus for exploring pollutant-degrading uncultured bacteria. SpringerPlus 2014 3:117.

\section{Submit your manuscript to a SpringerOpen ${ }^{\circ}$ journal and benefit from:}

- Convenient online submission

- Rigorous peer review

- Immediate publication on acceptance

- Open access: articles freely available online

- High visibility within the field

- Retaining the copyright to your article

Submit your next manuscript at $>$ springeropen.com 